\title{
Sacral Lymph Node
}

National Cancer Institute

\section{Source}

National Cancer Institute. Sacral Lymph Node. NCI Thesaurus. Code C77647.

A lymph node located in the sacral region. 